Check for updates

Cite this: RSC Adv., 2018, 8, 6425

Received 13th December 2017 Accepted 23rd January 2018

DOI: 10.1039/c7ra13309j

rsc.li/rsc-advances

\section{Isolation, identification and bioactivities of abietane diterpenoids from Premna szemaoensis $\dagger$}

De-Bing Pu, (D) t $^{\text {acd }}$ Ting Wang, t $^{\text {b }}$ Xing-Jie Zhang, ${ }^{a}$ Jun-Bo Gao, ${ }^{\text {cd }}$ Rui-Han Zhang, ${ }^{a}$ Xiao-Nian Li, ${ }^{c}$ Yong-Mei Wang, ${ }^{\text {cd }}$ Xiao-Li Li, ${ }^{* a} \mathrm{He}-$ Yao Wang ${ }^{\star b}$ and Wei-Lie Xiao (D)*ac

Investigation of the leaves and stems of Premna szemaoensis resulted in the isolation of twelve new abietane diterpenoids, szemaoenoids A-L (1-12), together with four known abietane diterpenoids (1316). The structures involved two rearranged-abietane skeletons: $17(15 \rightarrow 16)$-abeo-abietane $(7,10-12$, 14 and 15) and 17(15 $\rightarrow$ 16),18(4 $\rightarrow$ 3)-diabeo-abietane (1-6, 13 and 16). The structures of the new compounds were established mainly by analyzing NMR and HRESIMS data. The absolute configurations of 1,3 and 10 were confirmed by single crystal X-ray diffraction analysis. In bioactivity assays, compounds 11, 12, 14 and 15 were active against two human colon cancer cell lines (HCT-116 and HT29) with $I_{50}$ values ranging from 8.8 to $34.3 \mu \mathrm{M}$, and compounds 10,13 and 14 exhibited effective free radical scavenging activity with $\mathrm{IC}_{50}$ values ranging from 35.6 to $41.5 \mu \mathrm{M}$ by DPPH experiment.

\section{Introduction}

The genus Premna (family: Verbenaceae) comprises approximately 200 species, which are mainly distributed in the tropical zone of Asia and Africa. ${ }^{1}$ There are about 44 species and 5 varieties grown in the south of China, especially in Southwest China. The dried aerial parts of some Premna species have been used in traditional folk medicine for the treatment of pyogenic infections, trauma, fracture, dysentery, haemorrhoids, and rheumatic arthritis. ${ }^{2}$ Previous phytochemical investigations of Premna have indicated the presence of diterpenoids, ${ }^{3}$ flavonoids ${ }^{3-5}$ iridoid glycosides, ${ }^{4-7}$ xanthones, ${ }^{8}$ phenylethanoid glycosides, ${ }^{9}$ triterpenoids, ${ }^{10,11}$ and lignins. ${ }^{12}$ Their pharmacological effects, including neuroprotective, ${ }^{13}$ analgesic, ${ }^{14,15}$ antioxidative, cytotoxic, ${ }^{16,17}$ anti-inflammatory, ${ }^{18}$ and $\alpha$-glucosidase

${ }^{a}$ Key Laboratory of Medicinal Chemistry for Natural Resource of Ministry of Education, School of Chemical Science and Technology, State Key Laboratory for Conservation and Utilization of Bio-Resources in Yunnan, Yunnan University, Kunming 650091, People's Republic of China. E-mail: lixiaoli@ynu.edu.cn; xiaoweilie@ynu.edu.cn; Fax: +86 871-665033214; +86 871-67357014; Tel: +86 871-665033214; +86 87167357014

${ }^{b}$ State Key Laboratory of Drug Research, Shanghai Institute of Materia Medica, Chinese Academy of Sciences, Shanghai 201203, People's Republic of China. E-mail: hywang@ simm.ac.cn; Fax: +86 021-50807088; Tel: +86 021-50805785

${ }^{c}$ State Key Laboratory of Phytochemistry and Plant Resources in West China, Kunming Institute of Botany, Chinese Academy of Sciences, Kunming 650201, People's Republic of China

${ }^{d}$ University of Chinese Academy of Sciences, Beijing 100049, People's Republic of China $\dagger$ Electronic supplementary information (ESI) available: Detailed ${ }^{1} \mathrm{D}$ and ${ }^{2} \mathrm{D}$ NMR, HRESIMS, IR, UV and X-ray crystallographic data. CCDC 1554050-1554052. For ESI and crystallographic data in CIF or other electronic format see DOI: 10.1039/c7ra13309j

‡D.-B. Pu and T. Wang contributed equally to this work. inhibition, ${ }^{19}$ have been reported for crude extracts and pure compounds from Premna plants.

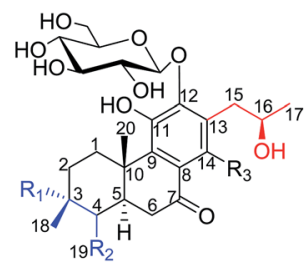

$1 \mathrm{R}_{1}=\mathrm{OH} \quad \mathrm{R}_{2}=\mathrm{CH}_{2} \quad \mathrm{R}_{3}=\mathrm{H} \Delta^{4,19}$

$2 \mathrm{R}_{2}=\mathrm{CH}_{2} \mathrm{OH} \mathrm{R}_{3}=\mathrm{H} \Delta^{3,4}$

$3 \mathrm{R}_{2}=\mathrm{CH}_{2} \mathrm{OH} \quad \mathrm{R}_{3}=\mathrm{OH} \Delta^{3,4}$ $16 \mathrm{R}_{2}=\mathrm{COOH} \mathrm{R}_{3}=\mathrm{H} \Delta^{3,4}$

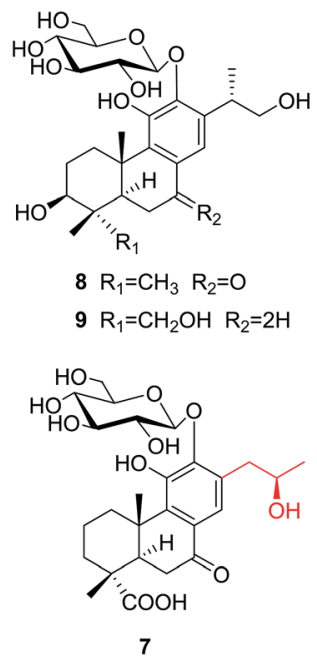<smiles>[R]C1=C[C@]2(C)c3c(c(O)c4cc(C)oc4c3O)C(=O)C[C@H]2C([R3])C1([R])C</smiles>

$4 \mathrm{R}_{1}=2 \mathrm{H} \mathrm{R}_{3}=\mathrm{CH}_{2} \mathrm{OH} \mathrm{R} \mathrm{R}_{4}=\mathrm{OGlc} \Delta^{3,4}$ $5 \quad \mathrm{R}_{1}=\mathrm{O} \quad \mathrm{R}_{3}=\mathrm{CH}_{2} \mathrm{OH} \quad \mathrm{R}_{4}=\mathrm{OGlc} \Delta^{3,4} \Delta^{5,6}$ $6 \mathrm{R}_{1}=2 \mathrm{H} \mathrm{R}_{2}=\mathrm{OH} \quad \mathrm{R}_{3}=\mathrm{CH}_{2} \mathrm{R}_{4}=\mathrm{OGlc} \Delta^{4,19}$ $13 \quad \mathrm{R}_{1}=\mathrm{O} \quad \mathrm{R}_{3}=\mathrm{CH}_{3} \quad \mathrm{R}_{4}=\mathrm{OH} \Delta^{3,4} \Delta^{5,6}$<smiles>[R2]C1Cc2c(O)c3c(c(O)c2O1)[C@@]1(C)CCC([R8])C(C)(C)[C@]1(C)[C@H]([R3])C3=O</smiles>

$10 \mathrm{R}_{1}=\mathrm{OH} \quad \mathrm{R}_{2}=\mathrm{CH}_{3} \mathrm{R}_{3}=\mathrm{H}$

$11 \mathrm{R}_{1}=\mathrm{OH} \quad \mathrm{R}_{2}=\mathrm{CH}_{3} \quad \mathrm{R}_{3}=\mathrm{H} \Delta^{15,16}$

$12 \mathrm{R}_{1}=\mathrm{H} \mathrm{R}_{2}=\mathrm{CH}_{2} \mathrm{OH} \mathrm{R}_{3}=\mathrm{H} \Delta^{15,16}$

$14 \mathrm{R}_{1}=\mathrm{H} \mathrm{R}_{2}=\mathrm{CH}_{2} \mathrm{OH} \mathrm{R}_{3}=\mathrm{H}$

$15 \mathrm{R}_{1}=\mathrm{H} \mathrm{R}_{2}=\mathrm{CH}_{3} \mathrm{R}_{3}=\mathrm{OCH}_{3} \Delta^{5,6}$

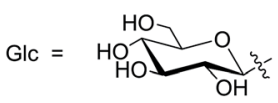

Premna szemaoensis Pei, locally called "simao dofu chai", is mainly distributed in the south of Yunnan province of China. ${ }^{20}$ 


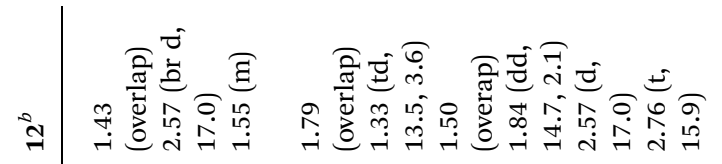
nat
$\hat{n}$
$b$
कृ

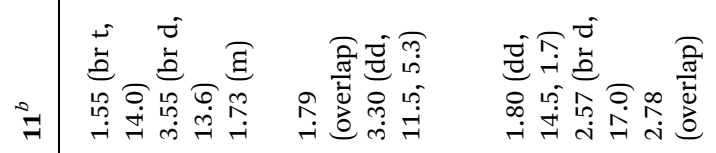

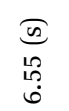

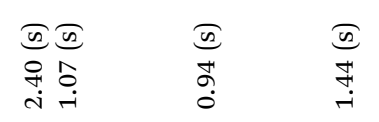

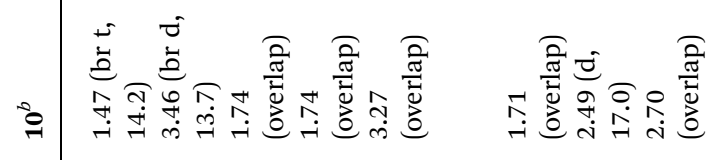

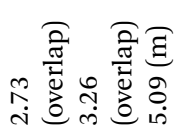
กู่

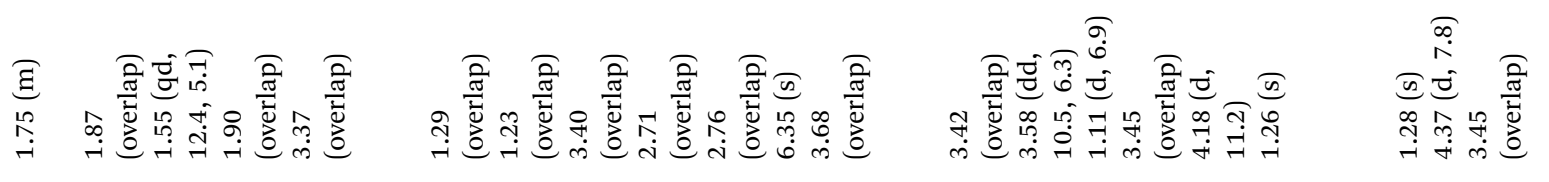

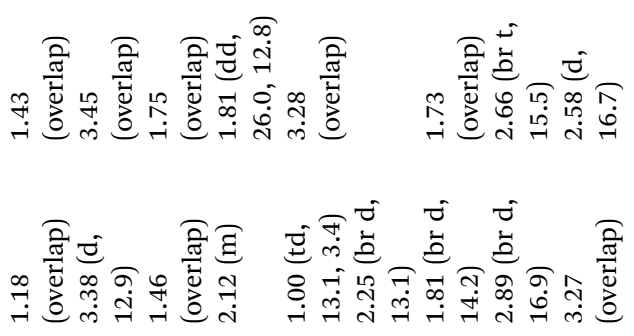

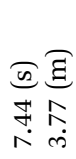

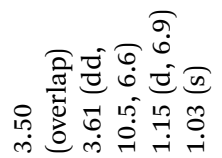

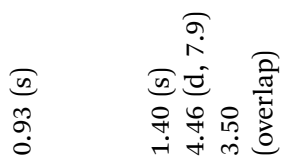

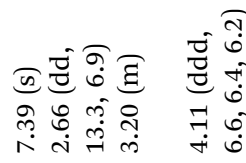

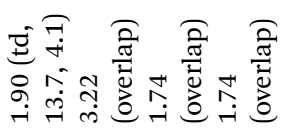
产芯茫
•

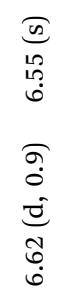

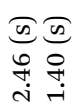

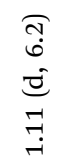

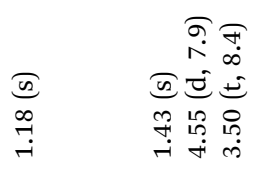

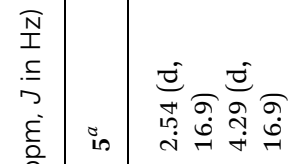

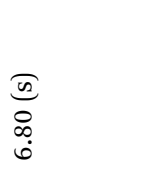

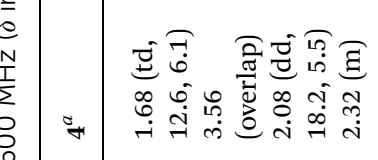

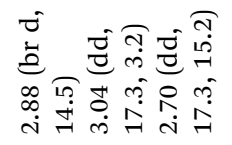

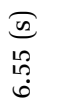

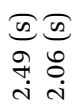

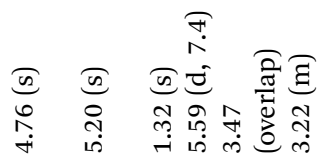

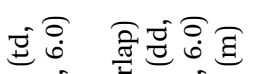

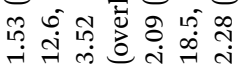

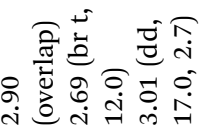

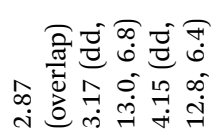

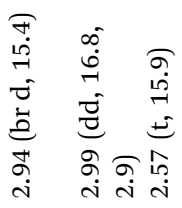

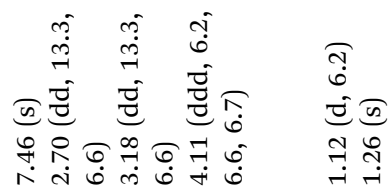

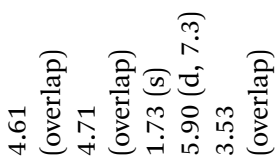

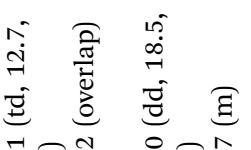

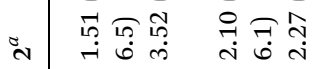

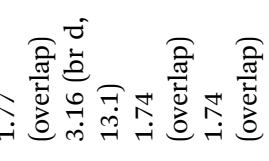

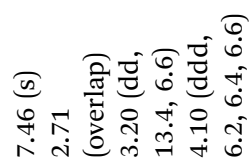
(됴
芒

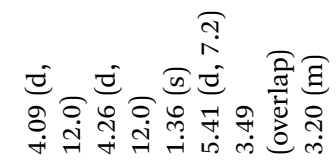

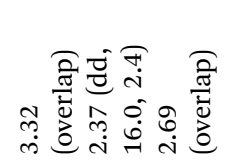
กृ?
$\rho_{\infty}^{\circ}$

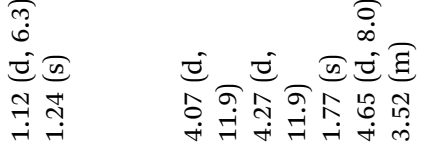

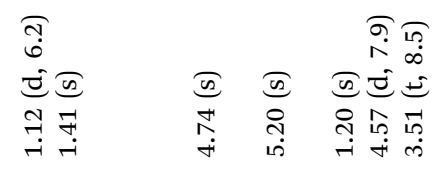




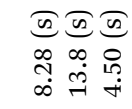

$\begin{array}{lll}\pi & \pi & \pi \\ 0 & 0 & \infty \\ 0 & -1 & \dot{n} \\ \dot{n} & \infty & -1\end{array}$

$$
\begin{aligned}
& \text { क }
\end{aligned}
$$

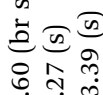

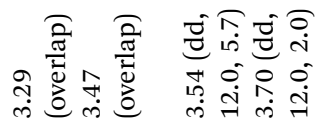
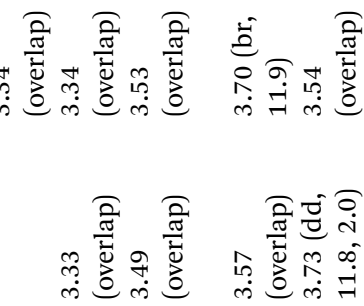

This plant has drawn the attention of local farmers and has been cultivated to be an important commercial crop due to its various applications. Its fresh leaves can be rubbed and squeezed in water to yield a mucilaginous juice, which was used to prepare a food named "green tofu" by local people through addition of materials containing $\mathrm{Ca}^{2+}$. In addition, the local villagers also used the leaves of this plant to cure injuries and fracture. ${ }^{20}$ However, the phytochemical investigation of this species was extremely rare, except a small number of flavonoids. In this investigation, we firstly afforded 12 new abietane diterpenoids (1-12) and four known abietane diterpenoids (13-16) from the aerial parts of $P$. szemaoensis. Most of the diterpenoids were with rearranged-abietane skeleton: $17(15 \rightarrow 16)$-abeoabietane framework or $17(15 \rightarrow 16), 18(4 \rightarrow 3)$-diabeo-abietane framework, which were mainly isolated from the plants of genus Clerodendron and reported bioactivities including cytotoxic, angiotensin converting enzyme (ACE) inhibitory, antiviral actives. ${ }^{21-24}$ Herein, we describe the isolation and structural elucidation of these diterpenoids and the biological activities of selected compounds.

\section{Results and discussion}

The aerial parts of $P$. szemaoensis were extracted three times with $70 \%$ acetone aqueous. After recycling acetone, the rest of portion was partitioned by liquid-liquid extraction between $n$ butanol and $\mathrm{H}_{2} \mathrm{O}$. The $n$-butanol-soluble portion was repeatedly subjected to silica gel, Sephadex LH-20, and RP-C18 gel column chromatography (CC) and semi-preparative HPLC to afford 16 abietane diterpenoids, including 12 new compounds. The structures and stereochemistry of these isolates were elucidated mainly using spectroscopic analysis, X-ray diffraction analysis, and compared to data in the literature. Ultimately, the new compounds were named as szemaoenoids A-L (1-12), and known compounds were identified as teuvincenone $\mathrm{F}(\mathbf{1 3}),{ }^{\mathbf{2 5}}$, (16R)-12,16-epoxy-11,14,17-trihydroxy-17(15 $\rightarrow \quad 16)$-abeo8,11,13-abieta-triene-7-one (villosin B) (14), ${ }^{26,27}$ 12,16-epoxy11,14,17-trihydroxy-6-methoxy-17(15 $\rightarrow$ 16)-abeo-5,8,11,13abietatetraene-7-one $\quad(\mathbf{1 5}),{ }^{28} \quad 11,16$-dihydroxy-12- $O$ - $\beta$-Dglucopyranosyl-17(15 $\rightarrow$ 16),18(4 $\rightarrow \quad 3)$-diabeo-4-carboxy$3,8,11,13$-abietatetraene-7-one (16), ${ }^{21}$ respectively.

Compound 1 was isolated as an optically active, white monoclinic crystals $(\mathrm{MeOH}) ;[\alpha]_{\mathrm{D}}^{25}+36.3$ ( $\left.c 0.10, \mathrm{MeOH}\right)$. Its HRESIMS data showed a sodium adduct ion $[\mathrm{M}+\mathrm{Na}]^{+}$at $m / z$ 531.2205 (calcd. for $\mathrm{C}_{26} \mathrm{H}_{36} \mathrm{NaO}_{10}, 531.2206$ ), which together with ${ }^{13} \mathrm{C}$ NMR (Table 2) and DEPT data were consistent with a molecular formula of $\mathrm{C}_{26} \mathrm{H}_{36} \mathrm{O}_{10}$, representing nine indices of hydrogen deficiency. The ${ }^{1} \mathrm{H}$ NMR spectrum of $\mathbf{1}$ (Table 1) showed one doublet and two singlets for methyl groups at $\delta_{\mathrm{H}}$ $1.12(\mathrm{~d}, J=6.2), 1.41(\mathrm{~s})$ and $1.20(\mathrm{~s})$, respectively; three olefinic proton signals at $\delta_{\mathrm{H}} 7.46(\mathrm{~s}), 5.20(\mathrm{~s})$, and $4.74(\mathrm{~s})$, and a double peak at $\delta_{\mathrm{H}} 4.57(\mathrm{~d}, J=7.9)$. The ${ }^{13} \mathrm{C}$ NMR and DEPT spectra of 1 (Table 2) showed signals of 20 carbons of an aglycon, attributable to a ketone group at $\delta_{\mathrm{C}} 200.7$, three methyls (two tertiary), five methylenes (one olefinic), three methines (one olefinic, one oxygenated), and eight quaternary carbons (six olefinic, one oxygenated), along with signals for a hexose unit. These data 


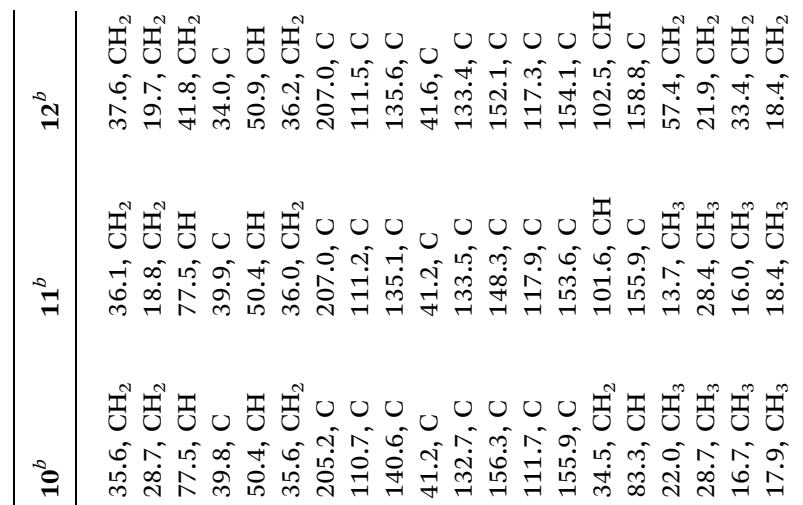

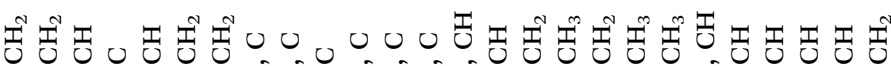

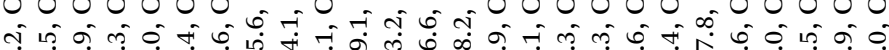
ब बें

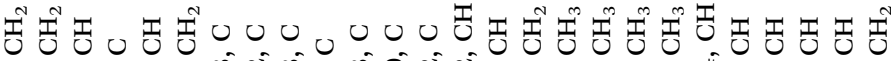
क न

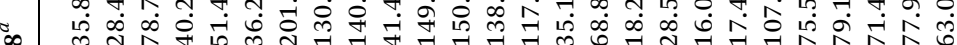

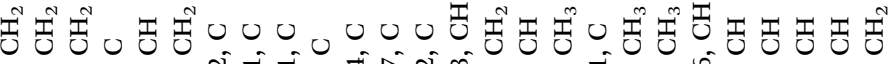

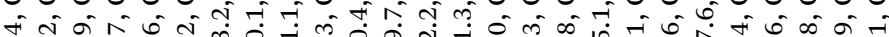
药

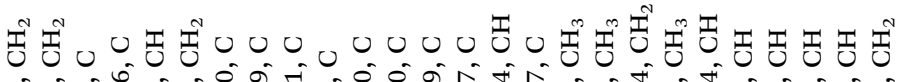
\#

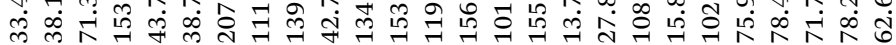

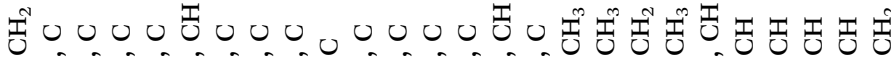

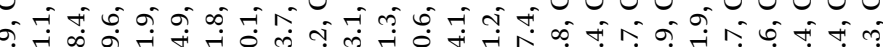
की

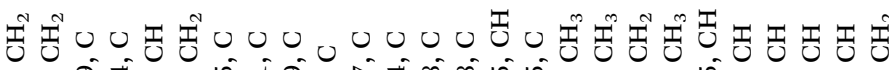

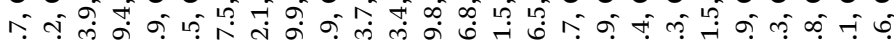
ले

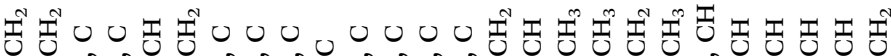

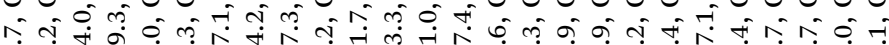

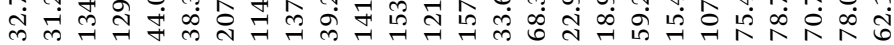

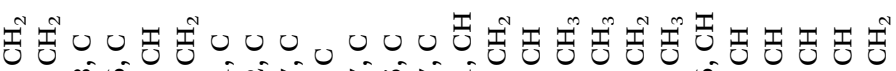
o f o b

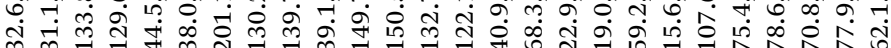

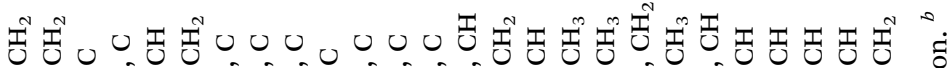
की

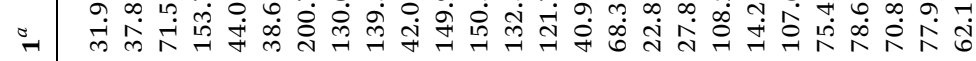


suggested that $\mathbf{1}$ is a diterpene glycoside and in accordance with the characteristics of a $17(15 \rightarrow 16), 18(4 \rightarrow 3)$-diabeo-8,11,13abietatriene.

The proton and protonated carbon NMR signals of 1 were assigned unambiguously by the HSQC experiment. Partial structures and the whole connection were deduced from correlations observed in the ${ }^{1} \mathrm{H}-{ }^{1} \mathrm{H}$ COSY and HMBC spectra (Fig. 1). The HMBC correlations of $\mathrm{CH}_{3}-18\left(\delta_{\mathrm{H}} 1.41\right)$ to $\mathrm{C}-2\left(\delta_{\mathrm{C}}\right.$ $37.8), \mathrm{C}-3\left(\delta_{\mathrm{C}} 71.5\right.$, an oxygenated quaternary carbon), and $\mathrm{C}-4$ $\left(\delta_{\mathrm{C}} 153.7\right.$, an olefinic quaternary carbon) and of $\mathrm{H}_{2}-19\left(\delta_{\mathrm{H}}\right.$ $4.74,5.20)$ to $\mathrm{C}-3 / \mathrm{C}-4 / \mathrm{C}-5\left(\delta_{\mathrm{C}} 44.0\right)$ suggested the presence of a $18(4 \rightarrow 3)$-abeo-abietane structural unit, established the location of an $\mathrm{OH}$ group at C-3 and an exocyclic double bond at $\mathrm{C}-4$ and $\mathrm{C}-19$. The ketone group was placed at C-7 from correlations of $\mathrm{H}-5\left(\delta_{\mathrm{H}} 3.32\right), \mathrm{H}_{2}-6\left(\delta_{\mathrm{H}} 2.37,2.69\right), \mathrm{H}-14\left(\delta_{\mathrm{H}} 7.46\right.$, one aromatic proton) to a ketone-group carbon $\left(\delta_{\mathrm{C}} 200.7\right) .{ }^{1} \mathrm{H}-{ }^{1} \mathrm{H}$ COSY correlations from $\mathrm{H}_{2}-15\left(\delta_{\mathrm{H}} 2.71,3.20\right)$ through $\mathrm{H}-16\left(\delta_{\mathrm{H}}\right.$ 4.10, an oxygenated proton) to $\mathrm{CH}_{3}-17\left(\delta_{\mathrm{H}} 1.12\right)$, in combination with $\mathrm{HMBC}$ correlations from $\mathrm{H}_{2}-15$ to $\mathrm{C}-12\left(\delta_{\mathrm{C}} 150.5\right)$ and C-14 $\left(\delta_{\mathrm{C}} 121.7\right)$, from $\mathrm{CH}_{3}-17$ to C-16 $\left(\delta_{\mathrm{C}} 68.3\right)$ and $\mathrm{C}-15\left(\delta_{\mathrm{C}} 40.9\right)$, were suggestive of $17(15 \rightarrow 16)$-abeo-abietane moiety in this structure, and an hydroxyl group at C-16. The location of the sugar moieties was determined by the HMBC correlation of the anomeric proton $\mathrm{H}-1^{\prime}\left(\delta_{\mathrm{H}} 4.57\right)$ to $\mathrm{C}-12$. In addition, ${ }^{1} \mathrm{H}-{ }^{1} \mathrm{H}$ COSY correlations: $\mathrm{H}_{2}-1 / \mathrm{H}_{2}-2, \mathrm{H}-5 / \mathrm{H}_{2}-6$, and $\mathrm{HMBC}$ correlations of $\mathrm{CH}_{3}-20$ to $\mathrm{C}-1, \mathrm{C}-9$ and $\mathrm{C}-10$, of $\mathrm{H}-5$ to $\mathrm{C}-4$ and C-10 were also key interactions to support this gross structure.

The $\beta$-D-configurational glucose unit was confirmed through coupling constant of $\mathrm{H}^{-1} \mathrm{1}^{\prime}(\mathrm{d}, J=7.9)$, acid hydrolysis and comparison with reference standard. In the case of abietane diterpenoid derivatives, relative configuration of $\mathrm{OH}$ at C-3 could be assigned for the $\alpha$ - and $\beta$-epimers, by NOE effect between $\mathrm{H}-3 / \mathrm{H}-5$ or $\mathrm{H}-3 / \mathrm{CH}_{3}-20$ respectively. However, the interaction of $\mathrm{CH}_{3}-18 / \mathrm{H}-5$ or $\mathrm{CH}_{3}-18 / \mathrm{CH}_{3}-20$ was not observed in 1. Its ROESY spectrum provided interactions of $\mathrm{CH}_{3}-18 / \mathrm{H}-2$ and $\mathrm{CH}_{3}-20 / \mathrm{H}-2$ (Fig. 1), but $\alpha$ - and $\beta$-H connected to C-2 displayed an overlapped signal at 1.74 in the ${ }^{1} \mathrm{H}$ NMR, which was not enough evidence to assign the C-3 configuration. Fortunately, appropriate crystals have been obtained, and the absolute configuration was assigned as $3 R, 5 R, 10 S, 16 R$ on the basis of the Flack parameter [0.17(14)] and Hooft parameter $[0.10(6)]$ for 1225 Bijvoet pairs obtained by low-temperature $[100(2) \mathrm{K}] \mathrm{Cu}$ $\mathrm{K} \alpha$ radiation X-ray crystallography (Fig. 2). ${ }^{29,30}$ Therefore, the
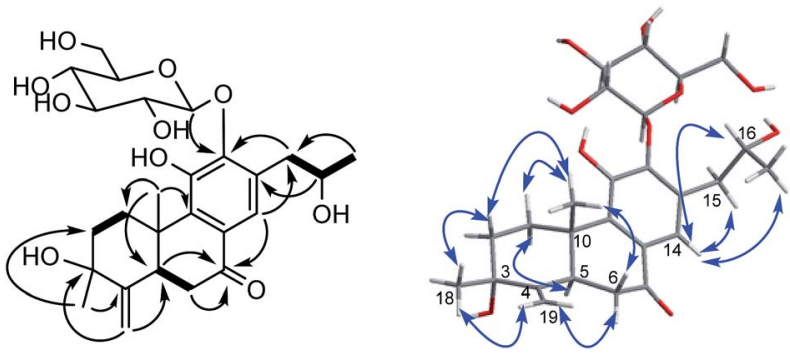

Fig. $1{ }^{1} \mathrm{H}-{ }^{1} \mathrm{H}$ COSY (bold), selected HMBC (arrow), and key ROESY (double arrow) correlations of 1. structure of 1 was elucidated as $(3 R, 16 R)-12-O-\beta-\mathrm{D}-$ glucopyranosyl-3,11,16-trihydroxy-17(15 $\rightarrow$ 16),18(4 $\rightarrow$ 3)-diabeo-4(19),8(9),11(12),13(14)-abietatetraene-7-one, named szemaoenoid A.

Compound 2 was isolated as a white amorphous powder with $[\alpha]_{\mathrm{D}}^{25}-8.8(c 0.14, \mathrm{MeOH})$. The HRESIMS gave a quasimolecular ion at $\mathrm{m} / z$ 531.2203 $[\mathrm{M}+\mathrm{Na}]^{+}$(calcd. for $\mathrm{C}_{26} \mathrm{H}_{36} \mathrm{NaO}_{10}$, 531.2206). Thus, in conjunction with ${ }^{13} \mathrm{C} \mathrm{NMR}$ and DEPT data, the molecular formula was established as $\mathrm{C}_{26} \mathrm{H}_{36} \mathrm{O}_{10}$, representing nine indices of hydrogen deficiency. The ${ }^{1} \mathrm{H}$ and ${ }^{13} \mathrm{C}$ NMR data of 2 (Tables 1 and 2) were similar to those of compound $\mathbf{1}$, with the differences being the presence of an oxygenated methylene $\left[\delta_{\mathrm{H}} 4.07(\mathrm{~d}, J=11.7), 4.27(\mathrm{~d}, J=11.7)\right.$, $\left.\delta_{\mathrm{C}} 59.2\right]$ and two olefinic quaternary carbons $\left(\delta_{\mathrm{C}} 133.8, \delta_{\mathrm{C}} 129.6\right)$ in 2 vs. an oxygenated quaternary carbon and an exocyclic double bond group in 1. Through HMBC experiment, observed correlations from $\mathrm{H}_{2}-19\left(\delta_{\mathrm{H}} 4.07,4.27\right)$ to $\mathrm{C}-3 / \mathrm{C}-4 / \mathrm{C}-5$, from $\mathrm{CH}_{3}$ $18\left(\delta_{\mathrm{H}} 1.26\right)$ to $\mathrm{C}-2 / \mathrm{C}-3 / \mathrm{C}-4$ indicated that an $\mathrm{OH}$ group at $\mathrm{C}-19$ and a double bond at $\mathrm{C}-3$ and $\mathrm{C}-4$. There was another hydroxyl group at C-16 (assigned the configuration as $R$ ) via comparing chemical shift and coupling constant of 2 with $\mathbf{1}\left[\delta_{\mathrm{H}-}\right.$ ${ }_{16} 4.11$ (ddd, $J=6.2,6.6,6.7$ ), $\delta_{\mathrm{C}-16} 68.3$ for $2 ; \delta_{\mathrm{H}-16} 4.10$ (ddd, $J=$ $6.2,6.4,6.6), \delta_{\mathrm{C}-16} 68.3$ for 1 ], and the connecting correlations of ${ }^{1} \mathrm{H}-{ }^{1} \mathrm{H}$ COSY and HMBC data.

So far, the vast majority of natural abietane-type diterpenes from plants share the same carbon skeleton, with a trans-fused system of two six-membered rings $A$ and $B$, a $\beta$-oriented methyl at C-10 and an $\alpha$-oriented proton at C-5. ${ }^{31}$ From biogenetic considerations, 2 was inferred as possessing an identical absolute configuration to 1 . Thus, the structure of 2 was established as (16R)-12- $O$ - $\beta$-D-glucopyranosyl-11,16,19-trihydroxy-17(15 $\rightarrow$ $16), 18(4 \rightarrow 3)$-diabeo-3(4),8(9),11(12),13(14)-abietatetraene-7-one, named szemaoenoid $B$.

Compound 3 was obtained as white monoclinic crystals $(\mathrm{MeOH})$. Its molecular formula assigned was determined to be $\mathrm{C}_{26} \mathrm{H}_{36} \mathrm{O}_{11}$ based on the negative HRESIMS $(\mathrm{m} / \mathrm{z} 523.2177$ [M $\mathrm{H}]^{-}$). The NMR data for this compound were highly close to those of 2 (Tables 1 and 2), except for presence of one olefinic quaternary carbon $\left(\delta_{\mathrm{C}} 157.4\right)$ in 3 , correspondingly absence of an olefinic methine $\left(\delta_{\mathrm{H}} 7.46, \delta_{\mathrm{C}} 122.1\right) v s$. 2. In the HMBC spectrum, the correlations of $\mathrm{H}_{2}-15\left(\delta_{\mathrm{H}} 2.87,3.17\right)$ to $\mathrm{C}-12\left(\delta_{\mathrm{C}}\right.$ 153.3), C-13 ( $\left.\delta_{\mathrm{C}} 121.0\right), \mathrm{C}-14\left(\delta_{\mathrm{C}} 157.4\right)$ indicated that an $\mathrm{OH}$ group was at $\mathrm{C}-14$, which made the chemical shifts of aromatic

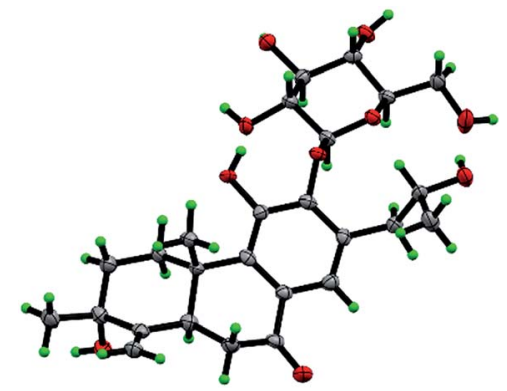

Fig. 2 ORTEP plot for the molecular structure of 1 drawn with 30\% probability displacement ellipsoids. 
fields and ketone group $\left(\delta_{\mathrm{C}} 207.1\right)$ obviously change in ${ }^{13} \mathrm{C}$ NMR spectrum vs. 2. Ultimately, the absolute configuration was confirmed by single crystal X-ray diffraction analysis, which assigned C-16 as $R$ configuration (Fig. 3). Therefore, the structure of 3 was determined as (16R)-12-O- $\beta$-D-glucopyranosyl11,14,16,19-tetrahydroxy-17(15 $\rightarrow$ 16),18(4 $\rightarrow \quad 3)$-diabeo3(4),8(9),11(12),13(14)-abietatetraene-7-one, named szemaoenoid C.

Compound 4, a yellowish amorphous powder, had a molecular formula of $\mathrm{C}_{26} \mathrm{H}_{32} \mathrm{O}_{10}$ according to HRESIMS $(\mathrm{m} / \mathrm{z} 527.1888$ $\left.[\mathrm{M}+\mathrm{Na}]^{+}\right)$. The ${ }^{1} \mathrm{H}$ NMR and ${ }^{13} \mathrm{C}$ NMR data were closely related to those of 3 (Tables 1 and 2). The differences were emergence of an olefinic double bond: one methine at C-15 $\left(\delta_{\mathrm{H}} 6.55, \mathrm{~s} ; \delta_{\mathrm{C}}\right.$ $101.5)$, one quaternary carbon at $\mathrm{C}-16\left(\delta_{\mathrm{C}} 156.5\right)$. The HMBC correlations from $\mathrm{CH}_{3}-17\left(\delta_{\mathrm{H}} 2.46, \mathrm{~s}\right)$ to $\mathrm{C}-15 / \mathrm{C}-16$ and from $\mathrm{H}^{-}$ 15 to $\mathrm{C}-12\left(\delta_{\mathrm{C}} 153.4\right) / \mathrm{C}-13\left(\delta_{\mathrm{C}} 119.8\right) / \mathrm{C}-14\left(\delta_{\mathrm{C}} 156.8\right)$ powerfully confirmed the locations of the double bond between C-15 and C16, and an $\mathrm{OH}$ group at $\mathrm{C}-16$. In consideration of its molecular formula as $\mathrm{C}_{26} \mathrm{H}_{32} \mathrm{O}_{10}$, and chemical stability, this structure must be absence of one $\mathrm{H}_{2} \mathrm{O}$, and linked from $\mathrm{C}-12$ to $\mathrm{C}-16$ through a vinyl ether bond, likewise the known compound $\mathbf{1 3}$ with a furan ring. The sugar moieties were determined to be located at C-11, by the HMBC correlation of the anomeric proton $\mathrm{H}-1^{\prime}\left(\delta_{\mathrm{H}} 5.41, \mathrm{~d}, 7.2\right)$ to $\mathrm{C}-11\left(\delta_{\mathrm{C}} 133.7\right)$. Thus, compound 4 was established as $11-O-\beta-\mathrm{D}^{-}$ glucopyranosyl-12,16-epoxy-14,19-dihydroxy-17(15 $\rightarrow$ 16),18(4 $\rightarrow$ 3)-diabeo-3(4),8(9),11(12),13(14),15(16)-abietapentaene-7-one, named szemaoenoid D.

Compound 5 was obtained as a brown amorphous powder. Its molecular formula was determined to be $\mathrm{C}_{26} \mathrm{H}_{28} \mathrm{O}_{11}$ by HRESIMS data, indicating 12 degrees of unsaturation (two more than that of compound 4). The ${ }^{1} \mathrm{H}$ and ${ }^{13} \mathrm{C}$ NMR resonances of 5 closely resembled those of $\mathbf{4}$ (Tables 1 and 2), except for appearance of a ketone group at $\mathrm{C}-2$ and a double bond at C-5/C-6. The HMBC correlations from $\mathrm{H}_{2}-1\left(\delta_{\mathrm{H}} 2.54, \mathrm{~d}, J=16.9\right.$ and $\delta_{\mathrm{H}} 4.29, \mathrm{~d}, J=$ 16.9) and $\mathrm{CH}_{3}-18\left(\delta_{\mathrm{H}} 2.06, \mathrm{~s}\right)$ to $\mathrm{C}-2\left(\delta_{\mathrm{C}} 201.1\right)$ and from $\mathrm{H}-6\left(\delta_{\mathrm{H}}\right.$ $6.80, \mathrm{~s})$ to $\mathrm{C}-4\left(\delta_{\mathrm{C}} 149.6\right) / \mathrm{C}-8\left(\delta_{\mathrm{C}} 110.1\right) / \mathrm{C}-10\left(\delta_{\mathrm{C}} 44.2\right)$ demonstrated above inference. Therefore, the structure of 5 was elucidated as 11-O- $\beta$-D-glucopyranosyl-12,16-epoxy-14,19-dihydroxy$17(15 \rightarrow 16), 18(4 \rightarrow$ 3)-diabeo-3(4),5(6),8(9),11(12),13(14),15(16)abietahexaene-2,7-dione, named szemaoenoid $\mathrm{E}$.

Compound 6 was isolated as a yellowish amorphous powder. The HRESIMS gave its molecular formula as $\mathrm{C}_{26} \mathrm{H}_{32} \mathrm{O}_{10}$ (being identical with 4). The NMR data of 6 (Tables 1 and 2) were

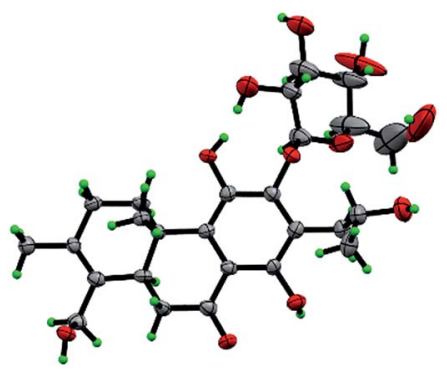

Fig. 3 ORTEP plot for the molecular structure of 3 drawn with $30 \%$ probability displacement ellipsoids. similar to those of $\mathbf{4}$, except for an oxygenated quaternary carbon $\left(\delta_{\mathrm{C}} 71.3\right)$ and an exocyclic double bond $\left[\delta_{\mathrm{C}} 153.6, \delta_{\mathrm{C}}\right.$ $108.4 ; \delta_{\mathrm{H}} 4.76,5.20$ ] in 6 (in accord with compound 1) vs. an oxygenated methylene and two olefinic quaternary carbons in 4 . In the HMBC spectrum, the cross-connection signals of $\mathrm{CH}_{3}-18$ $\left(\delta_{\mathrm{H}} 1.40\right)$ to C-2 $\left(\delta_{\mathrm{C}} 38.1\right), \mathrm{C}-3\left(\delta_{\mathrm{C}} 71.3\right)$ and $\mathrm{C}-4\left(\delta_{\mathrm{C}} 153.6\right)$, and of $\mathrm{H}_{2}-19\left[\delta_{\mathrm{H}} 4.76(\mathrm{~s}), 5.20(\mathrm{~s})\right]$ to $\mathrm{C}-3, \mathrm{C}-4$ and $\mathrm{C}-5\left(\delta_{\mathrm{C}} 43.7\right)$, supported the presence of an $\mathrm{OH}$ group at $\mathrm{C}-3$ and a double bond at C-4/C-19. In consideration of identical NMR data and biogenesis, absolute configuration of C-3 in 6 was identical with 1 (assigned as $R$ configuration). Consequently, compound $\mathbf{6}$ was established as (3R)-11- $O$ - $\beta$-D-glucopyranosyl-12,16-epoxy-3,14dihydroxy-17(15 $\rightarrow$ 16),18(4 $\rightarrow \quad 3)$-diabeo-4(19),8(9),11(12), 13(14),15(16)-abietapentaene-7-one, named szemaoenoid F.

Compound 7, a white amorphous powder, had a molecular formula of $\mathrm{C}_{26} \mathrm{H}_{36} \mathrm{O}_{11}$ on the basis of the HRESIMS. From the NMR data, it was similar to those of 2 (Tables 1 and 2), except for absence of two olefinic quaternary carbons $\left(\delta_{\mathrm{C}} 133.8,129.6\right)$ and an oxygenated methylene $\left(\delta_{\mathrm{C}} 59.2\right) v s$. 2, correspondingly presence of an obvious carboxyl $\left(\delta_{\mathrm{C}} 185.1\right)$, a quaternary carbon $\left(\delta_{\mathrm{C}} 45.7\right)$ and a methylene $\left(\delta_{\mathrm{C}} 39.9\right)$ in 7 . The HMBC correlations of $\mathrm{CH}_{3}-19\left(\delta_{\mathrm{H}} 1.18, \mathrm{~s}\right)$ to C-3 $\left(\delta_{\mathrm{C}} 39.9\right) / \mathrm{C}-4\left(\delta_{\mathrm{C}} 45.7\right) / \mathrm{C}-5\left(\delta_{\mathrm{C}} 53.6\right)$ and the carboxyl C-18 $\left(\delta_{\mathrm{C}} 185.1\right)$, of $\mathrm{H}-5\left(\delta_{\mathrm{H}} 1.81\right.$, br d, $\left.J=14.2\right)$ to $\mathrm{C}-4 / \mathrm{C}-18 / \mathrm{CH}_{3}-19\left(\delta_{\mathrm{C}} 30.1\right)$, and the ${ }^{1} \mathrm{H}-{ }^{1} \mathrm{H}$ COSY correlations of $\mathrm{H}_{2}-1 / \mathrm{H}_{2}-2 / \mathrm{H}_{2}-3$, all indicated that $\mathrm{CH}_{3}-19$ and the carboxyl C-18 were both linked to $\mathrm{C}-4$. $\mathrm{CH}_{3}-19$ was assigned as $\beta$-orientation from the NOE effect of $\mathrm{CH}_{3}-19 / \mathrm{CH}_{3}-20$. In view of identical NMR data and biogenesis, absolute configuration of C-16 in 7 was also identical with 1 (assigned as $R$ configuration). Therefore, the structure of 7 was determined as (16R)-12-O- $\beta$-Dglucopyranosyl-11,16-dihydroxy-17(15 $\rightarrow \quad 16)$-abeo8(9),11(12),13(14)-abietatriene-7-one-18-acid, named szemaoenoid G.

Compound 8, a white amorphous powder, exhibited a molecular formula of $\mathrm{C}_{26} \mathrm{H}_{38} \mathrm{O}_{10}$ according to HRESIMS. The ${ }^{1} \mathrm{H}$ and ${ }^{13} \mathrm{C}$ NMR spectra of 8 (Tables 1 and 2) were comparable with those of a known compound 12-O-D-glucopyranosyl3,11,16-trihydroxy-8,11,13-abietatriene. ${ }^{21}$ The evident difference was appearance of carbonyl group $\left(\delta_{\mathrm{C}} 201.3\right)$ in 8, but the known compound was absent of this group. The HMBC correlations of $\mathrm{H}-5\left(\delta_{\mathrm{H}} 1.73\right) / \mathrm{H}_{2}-6\left(\delta_{\mathrm{H}} 2.58,2.66\right) / \mathrm{H}-14\left(\delta_{\mathrm{H}} 7.44\right)$ with C-7 $\left(\delta_{\mathrm{C}}\right.$ 201.3), of $\mathrm{CH}_{3}-18\left(\delta_{\mathrm{H}} 1.03\right) / \mathrm{CH}_{3}-19\left(\delta_{\mathrm{H}} 0.93\right)$ with $\mathrm{C}-3\left(\delta_{\mathrm{C}} 78.7\right)$, and ${ }^{1} \mathrm{H}-{ }^{1} \mathrm{H}$ COSY connections of $\mathrm{H}_{2}-1 / \mathrm{H}_{2}-2 / \mathrm{H}-3$, suggested the carbonyl group at $\mathrm{C}-7$ and an $\mathrm{OH}$ group at $\mathrm{C}-3$, respectively. ${ }^{1} \mathrm{H}-{ }^{1} \mathrm{H}$ COSY correlations from $\mathrm{CH}_{3}-17\left(\delta_{\mathrm{H}} 1.15, \mathrm{~d}, J=6.3\right)$ through $\mathrm{H}-15\left(\delta_{\mathrm{H}} 3.77, \mathrm{~m}\right)$ to $\mathrm{CH}_{2}-16\left(\delta_{\mathrm{H}} 3.50,3.61\right.$, an oxygenated methylene), and $\mathrm{HMBC}$ correlations from $\mathrm{CH}_{3}-17$ to $\mathrm{C}-13$ $\left(\delta_{\mathrm{C}} 138.2\right)$ and $\mathrm{C}-15\left(\delta_{\mathrm{C}} 35.1\right)$, from $\mathrm{H}-15$ to $\mathrm{C}-16\left(\delta_{\mathrm{C}} 68.8\right), \mathrm{C}-17$ $\left(\delta_{\mathrm{C}} 18.2\right), \mathrm{C}-12$ and $\mathrm{C}-14$, were suggestive of an 1-hydroxyisopropyl moiety linked to $\mathrm{C}-13$ in this structure. Configurations of C-15 was established as $S$, by comparing the chemical shifts at C-13, C-15, C-16 with that of two known compounds (Table 3): (15S)-12-O-D-glucopy-ranosyl-3,11,16-trihydroxy$8,11,13$-abie-tatriene ${ }^{21}$ and (15R)-cyrtophyllone $\mathrm{B}^{32}$ whose structures were undoubtedly established by Mosher method and X-ray crystallography respectively. The $\beta$ orientation of $\mathrm{OH}-$ 3 was confirmed by the NOE effect of $\mathrm{H}-3 / \mathrm{H}-5$. Therefore, this 
Table 3 Comparison of partial NMR data of 8 and 9 with known compounds $^{a}$

\begin{tabular}{|c|c|c|c|c|c|c|c|c|c|}
\hline \multirow[b]{2}{*}{ Position } & \multicolumn{4}{|l|}{$\delta_{\mathrm{H}}$} & \multirow[b]{2}{*}{ Position } & \multicolumn{4}{|l|}{$\delta_{\mathrm{C}}$} \\
\hline & $\mathbf{a}$ & b & c & d & & $\mathbf{a}$ & b & c & d \\
\hline $\mathrm{H}-15$ & 3.69 & 3.15 & 3.77 & 3.68 & C-13 & 135.7 & 130 & 138.2 & 136.6 \\
\hline $\mathrm{H}-16 \mathrm{a}$ & 3.42 & 3.78 & 3.50 & 3.42 & C-15 & 35.1 & 39.1 & 35.1 & 34.9 \\
\hline$H-16 b$ & 3.58 & 3.94 & 3.61 & 3.58 & & & & & \\
\hline
\end{tabular}

structure was established as (15S)-12-O- $\beta$-D-glucopyranosyl$3 \beta, 11,16$-trihydroxy-8(9),11(12),13(14)-abietatriene-7-one, named szemaoenoid $H$.

The HREIMS and NMR data of compound 9 were consistent with the molecular formula of $\mathrm{C}_{26} \mathrm{H}_{40} \mathrm{O}_{10}$. Its ${ }^{1} \mathrm{H}$ and ${ }^{13} \mathrm{C} \mathrm{NMR}$ spectra (Tables 1 and 2) were almost identical with those of the known compound: 12-O-D-glucopyranosyl-3,11,16-trihydroxy$8,11,13$-abietatriene. ${ }^{21}$ In fact, the only difference was an oxygenated methylene $\left(\delta_{\mathrm{C}} 65.3\right)$ in 9 instead of a methyl group $\left(\delta_{\mathrm{C}}\right.$ 17.0) in the known structure. Moreover, the oxygenated methylene signals at $\delta_{\mathrm{H}} 3.45$ and 4.18 showed the HMBC correlations with the signals at C-3 $\left(\delta_{\mathrm{C}} 80.9\right)$, C-4 $\left(\delta_{\mathrm{C}} 44.3\right)$ and C$5\left(\delta_{\mathrm{C}} 55.0\right)$, and the NOE effect with $\mathrm{H}-5 / \mathrm{H}-3$, which evidently inferred that the $\mathrm{OH}$ was located at $\mathrm{C}-18$, in combination with NOE effect of $\mathrm{CH}_{3}-19 / \mathrm{CH}_{3}-20$. The $\beta$ orientation of $\mathrm{OH}-3$ and $S$ configuration of C-15 were confirmed like that of compound $\mathbf{8}$. Consequently, compound 9 was assigned as (15S)-12-O- $\beta$-Dglucopyranosyl-3 $\beta, 11,16,18$-tetrahydroxy-8(9),11(12),13(14)abietatriene, named szemaoenoid I.

Compound 10, yellowish monoclinic crystals (MeOH), its chemical formula as $\mathrm{C}_{20} \mathrm{H}_{26} \mathrm{O}_{5}$ was determined by HRESIMS, indicating 8 degrees of unsaturation in the structure. From the ${ }^{1} \mathrm{H}$ and ${ }^{13} \mathrm{C}$ NMR spectrum (Tables 1 and 2), its data was extremely similar to known compound 14, with a 17(15 $\rightarrow 16)$ abeo-abietane framework. Detailed HMBC and ${ }^{1} \mathrm{H}-{ }^{1} \mathrm{H}$ COSY NMR spectroscopic analyses (Fig. 4) suggested the appearance of an $\mathrm{OH}$ at C-3 $\left[\delta_{\mathrm{H}} 3.27 ; \delta_{\mathrm{C}} 77.5\right]$ and the absence of a hydroxy group at $\mathrm{C}-17$ in 10 by comparing with 14. A correlation observed in the ROESY spectrum (Fig. 4) between $\mathrm{H}-3$ and $\mathrm{H}-5$ $\left(\delta_{\mathrm{H}}\right.$ 1.71) indicated the $\beta$-orientation of $\mathrm{OH}-3$. The absolute configuration of this compound was established as $3 S, 5 R, 10 S$, $16 S$ by single crystal X-ray diffraction analysis (Fig. 5).
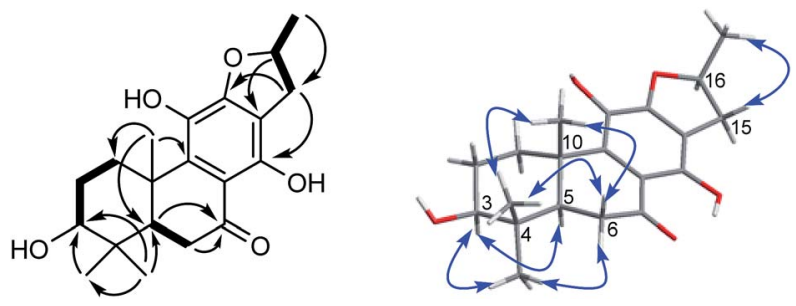

Fig. $4{ }^{1} \mathrm{H}-{ }^{1} \mathrm{H}$ COSY (bold), selected HMBC (arrow), and key ROESY (double arrow) correlations of 10.
Accordingly, the structure of 10 was assigned as $(3 S, 16 S)-12,16-$ epoxy-3,11,14-trihydroxy-17(15 $\rightarrow$ 16)-abeo-8(9),11(12),13(14)abietatriene-7-one, named szemaoenoid J.

Compound 11 and 12 were assigned to an identical molecular formula of $\mathrm{C}_{20} \mathrm{H}_{24} \mathrm{O}_{5}$ by HRESIMS data, with one more degree of unsaturation then 10. As seen from ${ }^{1} \mathrm{H}$ NMR and ${ }^{13} \mathrm{C}$ NMR spectrum (Tables 1 and 2), the structures of $\mathbf{1 1}$ and $\mathbf{1 2}$ were highly analogous to compound 10, except for the appearance of a double bond between C-15 and C-16 in 11 and 12, besides the presence of oxygenated methylene at C-17 $\left[\delta_{\mathrm{H}} 4.64\right.$, $\left.\mathrm{d}, J=5.9 ; \delta_{\mathrm{C}} 57.4\right]$ and the absence of $\mathrm{OH}-3$ in 12 . The positions of all functional groups in their structures were assigned by correlations of $\mathrm{HMBC}$ and ${ }^{1} \mathrm{H}-{ }^{1} \mathrm{H}$ COSY spectrum. The $\beta$ orientation of $\mathrm{OH}-3$ in $\mathbf{1 1}$ was confirmed by ROESY correlation of $\mathrm{H}-3 / \mathrm{H}-5$ and comparing with NMR data with those of $\mathbf{1 0 .}$ Therefore, their structures were established as 12,16-epoxy3ß,11,14-trihydroxyl-17(15 $\rightarrow$ 16)-abeo-8(9),11(12),13(14),15(16)abietatetraene-7-one (11), named szemaoenoid K; and 12,16epoxy-11,14,17-trihydroxy-17(15 $\rightarrow \quad 16)$-abeo-8(9),11(12), 13(14),15(16)-abietatetraene-7-one (12), named szemaoenoid L.

In our cognition, many diterpenoides had been reported from plants of Premna genus, ${ }^{33-36}$ but this was also the first to report diterpenoids isolated from the Premna plants distributed in China, and the described rearranged-abietane skeletons were firstly isolated from Premna genus. Abietane diterpenoids represented a large group of secondary metabolites that have shown interesting biological activities. ${ }^{31}$ But the rearranged abietane diterpenoids with $17(15 \rightarrow 16)$-abeo-abietane or 17(15 $\rightarrow 16), 18(4 \rightarrow 3)$-diabeo-abietane were not common in nature. Structurally, the rearranged diterpenoids contain abundant hydroxyl groups and aromatic carbons, as well as trans-fused rings $\mathrm{A}$ and $\mathrm{B}$ according to biosynthetic pathway. However, the stereocenter of C-16 replaced with $\mathrm{OH}$ had never been established previously. Within this work, we firstly employed X-ray crystallography to assign absolute configuration of C-16 for a small series of 16-hydroxy-17(15 $\rightarrow$ 16)-abeo-abietane diterpenoids, which might assist future unambiguous identification of structurally related compounds.

All the above compounds, except 3, 4 and 10, were evaluated for cytotoxicity in vitro against two human colon carcinoma cell lines (HCT-116 and HT-29). As a result (Table 4), compounds 11-15 showed antiproliferative activity against HCT-116 cell line, and compounds 11, 12 and 15 also exhibited potent cytotoxicity on HT-29 colon carcinoma cell line. Impressively, the

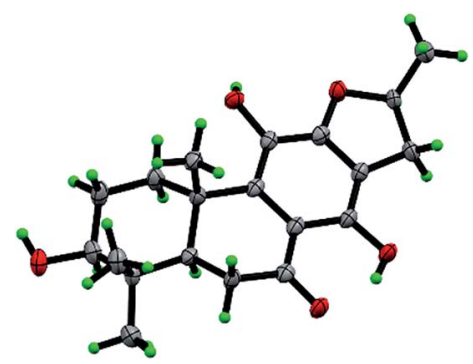

Fig. 5 ORTEP plot for the molecular structure of 10 drawn with $30 \%$ probability displacement ellipsoids. 
Table $4 \quad I C_{50}$ values $(\mu \mathrm{M} \pm \mathrm{SD})$ obtained for the compounds against HCT-116 and HT-29 cell lines ${ }^{a}$

\begin{tabular}{lll}
\hline & \multicolumn{2}{l}{$\mathrm{IC}_{50}(\mathrm{mean} \pm \mathrm{SD}, \mu \mathrm{M})$} \\
\cline { 2 - 3 } Compound & $\mathrm{HCT}-116$ & $\mathrm{HT}-29$ \\
\hline $\mathbf{1 1}$ & $30.5 \pm 4.7$ & $21.3 \pm 2.9$ \\
$\mathbf{1 2}$ & $24.1 \pm 4.5$ & $34.6 \pm 3.4$ \\
$\mathbf{1 3}$ & $34.3 \pm 2.8$ & $\mathrm{NA}$ \\
$\mathbf{1 4}$ & $17.7 \pm 4.6$ & $8.7 \pm 1.4$ \\
Sorafenib & $20.1 \pm 3.0$ & $14.2 \pm 2.6$ \\
& $8.5 \pm 1.1$ & $8.4 \pm 1.3$
\end{tabular}

${ }^{a}$ NA means that compounds exhibited indistinctive activity against tumor cells, and $\mathrm{IC}_{50}$ values were not evaluated.

antiproliferation activity of compound $\mathbf{1 4}$ was comparable $\left(\mathrm{IC}_{50} 8.7\right.$ $\pm 1.4 \mu \mathrm{M}$ ) with positive control (sorafenib, $\mathrm{IC}_{50} 8.4 \pm 1.3 \mu \mathrm{M}$ ) (Table 4). Almost all the diterpene aglycones showed effective cytotoxicity, but none of the diterpene glucosides exhibited remarkable activity. The reason might be that the glucosides with strong chemical polarity failed to penetrate the liposoluble cell membrane.

As most of natural products possessing phenolic hydroxy exhibited antioxidant activity, ${ }^{37-39}$ some selective compounds of the diterpenosides were executed free radical scavenging activity assay in the DPPH experiment (Table 5). Among the tested compounds, diterpene aglycones 13, 14 showed strong free radical scavenging activity with $\mathrm{IC}_{50}$ values of $41.5 \pm 17.0$ and $39.9 \pm 12.9 \mu \mathrm{M}$ respectively, and compound 10 was especially the strongest activity with $\mathrm{IC}_{50} 35.6 \pm 9.8 \mu \mathrm{M}$ (more potent than the positive control trolox and vitamin C). Compound 12 exhibited slightly weaken antioxidant activity with $\mathrm{IC}_{50}$ values of $74.9 \pm 6.9 \mu \mathrm{M}$. None of the tested diterpene glucosides (1, 2, 3, 5, 9 and 16) showed potent free radical scavenging activity. Concerning the structure-activity relationship, a reasonable conclusion was reasoned out that the more the structure possessed phenolic hydroxyl groups, the more its scavenging activity was strong.

Table 5 DPPH free radical scavenging activity for the compounds ${ }^{a}$

\begin{tabular}{ll}
\hline Compound & $\mathrm{IC}_{50}($ mean $\pm \mathrm{SD}, \mu \mathrm{M})$ \\
\hline $\mathbf{1}$ & $>200$ \\
$\mathbf{2}$ & $>200$ \\
$\mathbf{3}$ & $>200$ \\
$\mathbf{5}$ & $149.5 \pm 51.1$ \\
$\mathbf{9}$ & $>200$ \\
$\mathbf{1 0}$ & $35.6 \pm 9.8$ \\
$\mathbf{1 2}$ & $74.9 \pm 6.9$ \\
$\mathbf{1 3}$ & $41.5 \pm 17.0$ \\
$\mathbf{1 4}$ & $39.9 \pm 12.9$ \\
$\mathbf{1 6}$ & $>200$ \\
Trolox & $36.3 \pm 5.6$ \\
Ascorbic acid (vitamin C) & $39.1 \pm 6.7$
\end{tabular}

${ }^{a} \mathrm{IC}_{50}, 50 \%$ inhibitory concentration. Mean activity of $\mathrm{IC}_{50}$ was exhibited by mean \pm standard deviation, $n \geq 3$.

\section{Experimental section}

\section{General experimental procedures}

X-ray data were collected using a Bruker APEX DUO instrument. Optical rotations were measured with Horiba SEPA-300 and JASCO P-1020 polarimeters. UV spectra were recorded on a Shimadzu UV-2401A spectrophotometer. IR spectra were obtained on a Tenor 27 spectrophotometer with $\mathrm{KBr}$ pellets. Onedimensional (1D) and two-dimensional (2D) NMR spectra were recorded on Bruker DRX-600 spectrometers with TMS as the internal standard. Chemical shifts $(\delta)$ were expressed in parts per million with reference to the solvent signals. HRESIMS was performed on an Agilent G6230 TOF MS. Semi-preparative HPLC was performed on an Agilent 1260 liquid chromatograph with a Zorbax SB-C18 $(9.4 \mathrm{~mm} \times 25 \mathrm{~cm})$ column. Column chromatography (CC) was performed on silica gel (100-200 mesh and 200-300 mesh; Qingdao Marine Chemical Inc., Qingdao, People's Republic of China), Lichroprep RP-18 gel (40$63 \mu \mathrm{m}$, Merck, Darmstadt, Germany), MCI gel (75-150 $\mu \mathrm{m}$, Mitsubishi Chemical Corporation, Tokyo, Japan), and Sephadex LH-20 (Pharmacia). Fractions were monitored by TLC, and spots were visualized by UV light $(254 \mathrm{~nm})$ and sprayed with $8 \%$ $\mathrm{H}_{2} \mathrm{SO}_{4}$ in ethanol, followed by heating.

\section{Plant materials}

Aerial parts of Premna szemaoensis were collected in February 2012 from Puer city, Yunnan Province, People's Republic of China, and identified by Researcher Xi-Wen Li, Kunming Institute of Botany. A voucher specimen (XWL20140403) has been deposited in the Herbarium of the Kunming Institute of Botany, Chinese Academy of Sciences.

\section{Extraction and isolation}

The air-dried and powdered aerial parts of P. szemaoensis (10 kg) were extracted with $70 \%$ aqueous acetone $(40 \mathrm{~L})$ four times (two days each time) at room temperature and then filtered. The filtrate was evaporated under reduced pressure at $40{ }^{\circ} \mathrm{C}$ and then partitioned between $n$-butanol and $\mathrm{H}_{2} \mathrm{O}$. The $n$-butyl alcohol soluble portion (600 g) was subjected to silica gel CC (2.5 kg, 100-200 mesh), eluted with a $\mathrm{CHCl}_{3}-\mathrm{Me}_{2} \mathrm{CO}$ gradient system $(1: 0-0: 1)$ that afforded fractions A-E. The fractions were then decolorized using MCI gel and eluted with 95\% $\mathrm{MeOH}^{-}$ $\mathrm{H}_{2} \mathrm{O}$.

Fraction B (33 g) was subjected to silica gel CC (200-300 mesh), eluted with a $\mathrm{CHCl}_{3}-\mathrm{MeOH}$ gradient (150:1-1:1), to yield fractions B1-B5. Fraction B1 was purified by repeated silica gel CC (petroleum ether- $\mathrm{Me}_{2} \mathrm{CO}$ gradient, 12:1-0:1) to yield compound 14 (10.2 mg). Fraction B3 was purified by Sephadex LH-20 (MeOH) to yield fractions B31-B34. Then compound 13 (75.0 mg) was crystallized from fraction B34, and compound 15 $(8.4 \mathrm{mg})$ was isolated by HPLC $\left(78 \% \mathrm{MeOH}-\mathrm{H}_{2} \mathrm{O}, R_{\mathrm{t}}=15.2\right.$ min). B4 was purified by RP-18 CC $\left(\mathrm{MeOH}-\mathrm{H}_{2} \mathrm{O}\right.$ gradient, 30$100 \%$ ) to yield fractions $\mathrm{B} 41-\mathrm{B} 45$, then $\mathrm{B} 43$ was isolated by semi-preparative $\mathrm{HPLC}\left(72 \% \mathrm{MeOH}-\mathrm{H}_{2} \mathrm{O}, R_{\mathrm{t}}=13.5 \mathrm{~min}\right)$ to obtain compound 10 (10.1 mg). B5 was subjected to Sephadex LH-20 CC (MeOH) to give B51-B55, then compounds 11 (8.7 mg) 
and 12 (15.4 mg) were isolated from fraction B52 by semipreparative $\mathrm{HPLC}\left(75 \% \mathrm{MeOH}-\mathrm{H}_{2} \mathrm{O}, R_{\mathrm{t}}=13.1\right.$ and $14.8 \mathrm{~min}$, respectively).

Fraction C (120 g) was separated by Sephadex LH-20 (MeOH) to give fractions $\mathrm{C} 1-\mathrm{C} 5$. Fraction $\mathrm{C} 2$ was subjected to repeated silica gel CC (200-300 mesh), eluted with $\mathrm{CHCl}_{3}-\mathrm{MeOH}$ (gradient system: 120:1-1:1) to yield fractions C21-C27. C23 was isolated by semi-preparative HPLC $\left(42 \% \mathrm{MeOH}-\mathrm{H}_{2} \mathrm{O}, R_{\mathrm{t}}=15.1\right.$ and $13.2 \mathrm{~min}$, respectively) to afford compounds 1 (8.5 $\mathrm{mg}$ ) and 2 (11.7 mg). C25 was purified by HPLC $\left(44 \% \mathrm{MeOH}-\mathrm{H}_{2} \mathrm{O}, R_{\mathrm{t}}=\right.$ 10.3, 15.3 and $14.5 \mathrm{~min}$, respectively) to yield compounds 4 (5.2 $\mathrm{mg}), 5$ (4.6 mg), and 6 (2.3 mg).

Fraction D (100 g) was subjected to RP-18 CC $\left(\mathrm{MeOH}-\mathrm{H}_{2} \mathrm{O}\right.$, $10-100 \%)$ to give fractions D1-D6. Compound $16(20.1 \mathrm{mg})$ was crystallized from fractions D2. Fraction D4 was separated to by Sephadex LH-20 eluted with MeOH to give D41-D47, then D43 was isolated by semi-preparative HPLC $\left(41 \% \mathrm{MeOH}-\mathrm{H}_{2} \mathrm{O}, R_{\mathrm{t}}=\right.$ 14.5 and $7.8 \mathrm{~min}$, respectively) to yield compounds $3(6.1 \mathrm{mg})$ and 7 (4.3 mg). Fraction D5 was separated to silica gel CC (200300 mesh) eluted with $\mathrm{CHCl}_{3}-\mathrm{MeOH}$ (50:1-1:2) to yield D51D56, then D54 was followed by HPLC $\left(44 \% \mathrm{MeOH}-\mathrm{H}_{2} \mathrm{O}, R_{\mathrm{t}}=\right.$ 15.5 and $14.2 \mathrm{~min}$, respectively) to afford compounds 8 (4.6 mg) and 9 (2.3 $\mathrm{mg})$.

Szemaoenoid A (1). White monoclinic crystals (MeOH); mp $257-259{ }^{\circ} \mathrm{C}(\mathrm{MeOH}) ;[\alpha]_{\mathrm{D}}^{22}+36.3(c 0.10, \mathrm{MeOH}) ; \mathrm{UV}(\mathrm{MeOH}) \lambda_{\max }$ (log $\varepsilon) 213$ (4.23), 269 (3.91), 318 (3.49) nm; IR (KBr) $\nu_{\max } 3441$, 1632, $1049 \mathrm{~cm}^{-1} ;{ }^{1} \mathrm{H}$ and ${ }^{13} \mathrm{C}$ NMR data, see Tables 1 and 2; positive-ion ESIMS $m / z 531[\mathrm{M}+\mathrm{Na}]^{+}$; positive-ion HRESIMS [M $+\mathrm{Na}]^{+} \mathrm{m} / z 531.2205$ (calcd for 531.2206).

Szemaoenoid B (2). White amorphous powder; $[\alpha]_{\mathrm{D}}^{22}+28.8(c$ 0.14, MeOH); UV (MeOH) $\lambda_{\max }(\log \varepsilon) 204$ (4.17), 270 (3.96), 318 (3.32) nm; IR (KBr) $\nu_{\max } 3441,1632,1071 \mathrm{~cm}^{-1} ;{ }^{1} \mathrm{H}$ and ${ }^{13} \mathrm{C}$ NMR data, see Tables 1 and 2; positive-ion ESIMS $m / z 531[\mathrm{M}+\mathrm{Na}]^{+}$; positive-ion HRESIMS $[\mathrm{M}+\mathrm{Na}]^{+} \mathrm{m} / z \quad 531.2203$ (calcd for 531.2206).

Szemaoenoid C (3). White monoclinic crystals (MeOH); mp $275-278{ }^{\circ} \mathrm{C}(\mathrm{MeOH}) ;[\alpha]_{\mathrm{D}}^{22}+17.8(c 0.12, \mathrm{MeOH}) ; \mathrm{UV}(\mathrm{MeOH}) \lambda_{\max }$ $(\log \varepsilon) 203$ (4.55), 239 (1.55), 283 (1.51) nm; IR (KBr) $\nu_{\max } 3414$, 1616, 1424, $1072 \mathrm{~cm}^{-1} ;{ }^{1} \mathrm{H}$ and ${ }^{13} \mathrm{C}$ NMR data, see Tables 1 and 2; negative-ion ESIMS $m / z 523[\mathrm{M}-\mathrm{H}]^{-}$; negative-ion HRESIMS $[\mathrm{M}-\mathrm{H}]^{-} m / z 523.2177$ (calcd for 523.2179).

Szemaoenoid D (4). Yellowish amorphous powder; $[\alpha]_{\mathrm{D}}^{22}-54.1$ ( c 0.04, MeOH); UV (MeOH) $\lambda_{\max }(\log \varepsilon) 204$ (4.47), 239(4.41), 254 (4.33), 355 (3.61) nm; IR (KBr) $\nu_{\max } 3425,2924$, 1631, 1384, 1069, $586 \mathrm{~cm}^{-1} ;{ }^{1} \mathrm{H}$ and ${ }^{13} \mathrm{C}$ NMR data, see Tables 1 and 2; positive-ion ESIMS $\mathrm{m} / z 527[\mathrm{M}+\mathrm{Na}]^{+}$; positive-ion HRESIMS $[\mathrm{M}+\mathrm{Na}]^{+} \mathrm{m} / z 527.1888$ (calcd for 527.1893).

Szemaoenoid E (5). Brown amorphous powder; $[\alpha]_{\mathrm{D}}^{22}-53.0(c$ 0.10, MeOH); UV (MeOH) $\lambda_{\max }(\log \varepsilon) 202$ (4.13), 295 (4.06) nm; IR $(\mathrm{KBr}) \nu_{\max } 3426,1629,1466,1216,580 \mathrm{~cm}^{-1} ;{ }^{1} \mathrm{H}$ and ${ }^{13} \mathrm{C}$ NMR data, see Tables 1 and 2; positive-ion ESIMS $m / z 539[\mathrm{M}+\mathrm{Na}]^{+}$; positive-ion HRESIMS $[\mathrm{M}+\mathrm{Na}]^{+} \mathrm{m} / z \quad 539.1519$ (calcd for 539.1529).

Szemaoenoid F (6). Yellowish amorphous powder; $[\alpha]_{\mathrm{D}}^{22}+78.8$ (c 0.06, MeOH); UV (MeOH) $\lambda_{\max }(\log \varepsilon) 202$ (4.27), 240 (4.34), 254 (4.27), 356 (3.52) nm; IR (KBr) $\nu_{\max } 3422,2924,1635,1357$, 1201, $1077 \mathrm{~cm}^{-1} ;{ }^{1} \mathrm{H}$ and ${ }^{13} \mathrm{C}$ NMR data, see Tables 1 and 2; negative-ion ESIMS $m / z 503[\mathrm{M}-\mathrm{H}]^{-}$; negative-ion HREIMS [M $-\mathrm{H}]^{-} m / z 503.1912$ (calcd for 503.1917).

Szemaoenoid G (7). White amorphous powder; $[\alpha]_{\mathrm{D}}^{22}+15.9(c$ 0.13, MeOH); UV (MeOH) $\lambda_{\max }(\log \varepsilon) 215$ (4.25), 269 (3.84), 316 (3.44) nm; IR (KBr) $\nu_{\max } 3441,1632,1068 \mathrm{~cm}^{-1} ;{ }^{1} \mathrm{H}$ and ${ }^{13} \mathrm{C} \mathrm{NMR}$ data, see Tables 1 and 2; negative-ion ESIMS $m / z 523[\mathrm{M}-\mathrm{H}]^{-}$; negative-ion HRESIMS $[\mathrm{M}-\mathrm{H}]^{-} m / z 523.2176$ (calcd for 523.2179).

Szemaoenoid $\mathbf{H}(\mathbf{8})$. White amorphous powder; $[\alpha]_{\mathrm{D}}^{22}-8.57(c$ 0.07, MeOH); UV (MeOH) $\lambda_{\max }(\log \varepsilon) 215$ (4.11), 269 (3.76), 316 (3.33) nm; IR (KBr) $\nu_{\max } 3428,1632,1069 \mathrm{~cm}^{-1} ;{ }^{1} \mathrm{H}$ and ${ }^{13} \mathrm{C}$ NMR data, see Tables 1 and 2; negative-ion ESIMS $m / z 509[\mathrm{M}-\mathrm{H}]^{-}$; negative-ion HRESIMS $[\mathrm{M}-\mathrm{H}]^{-} m / z 509.2388$ (calcd for 509.2387).

Szemaoenoid I (9). White amorphous powder; $[\alpha]_{\mathrm{D}}^{22}+9.25(c$ 0.09, MeOH); UV (MeOH) $\lambda_{\max }(\log \varepsilon) 204$ (4.65), 275 (3.27) nm; IR $(\mathrm{KBr}) \nu_{\max } 3424,1632,1422,1063,596 \mathrm{~cm}^{-1} ;{ }^{1} \mathrm{H}$ and ${ }^{13} \mathrm{C} \mathrm{NMR}$ data, see Tables 1 and 2; negative-ion ESIMS $m / z 511[\mathrm{M}-\mathrm{H}]^{-}$; negative-ion HRESIMS $[\mathrm{M}-\mathrm{H}]^{-} \mathrm{m} / z \quad 511.2540$ (calcd for 511.2543).

Szemaoenoid J (10). Yellowish monoclinic crystals $(\mathrm{MeOH})$; mp 213-215 ${ }^{\circ} \mathrm{C}(\mathrm{MeOH}) ;[\alpha]_{\mathrm{D}}^{22}+30.56(c 0.12, \mathrm{MeOH}) ; \mathrm{UV}(\mathrm{MeOH})$ $\lambda_{\text {max }}(\log \varepsilon) 203$ (4.84), 212 (4.70), 298 (3.10), 353 (1.67) nm; IR (KBr) $\nu_{\max } 3427,1632,1462,1351,1015 \mathrm{~cm}^{-1} ;{ }^{1} \mathrm{H}$ and ${ }^{13} \mathrm{C}$ NMR data, see Tables 1 and 2; negative-ion ESIMS $m / z 345[\mathrm{M}-\mathrm{H}]^{-}$; negative-ion HRESIMS $[\mathrm{M}-\mathrm{H}]^{-} \mathrm{m} / z \quad 345.1708$ (calcd for 345.1702).

Szemaoenoid $\mathbf{K}$ (11). Yellowish amorphous powder; $[\alpha]_{\mathrm{D}}^{22}+61.3(c 0.10, \mathrm{MeOH}) ; \mathrm{UV}(\mathrm{MeOH}) \lambda_{\max }(\log \varepsilon) 202$ (4.23), 237 (4.25), 258 (4.18), 369 (3.52) nm; IR (KBr) $\nu_{\max } 3441,1631$, 1458, 1372, 1277, 1179, 1069, $602 \mathrm{~cm}^{-1} ;{ }^{1} \mathrm{H}$ and ${ }^{13} \mathrm{C}$ NMR data, see Tables 1 and 2; negative-ion ESIMS $m / z 343[\mathrm{M}-\mathrm{H}]^{-}$; negative-ion HRESIMS $[\mathrm{M}-\mathrm{H}]^{-} m / z \quad 343.1551$ (calcd for 343.1546).

Szemaoenoid L (12). Yellowish amorphous powder; $[\alpha]_{\mathrm{D}}^{22}+43.3(c 0.11, \mathrm{MeOH}) ; \mathrm{UV}(\mathrm{MeOH}) \lambda_{\max }(\log \varepsilon) 202$ (3.99), 237 (4.06), 260 (4.02), 366 (3.36) nm; IR (KBr) $\nu_{\max } 3429,2926$, 1631, 1456, $1370 \mathrm{~cm}^{-1} ;{ }^{1} \mathrm{H}$ and ${ }^{13} \mathrm{C}$ NMR data, see Tables 1 and 2; negative-ion ESIMS $m / z 343[\mathrm{M}-\mathrm{H}]^{-}$; negative-ion HRESIMS $[\mathrm{M}-\mathrm{H}]^{-} \mathrm{m} / \mathrm{z} 343.1548$ (calcd for 343.1546).

\section{$\mathrm{X}$-ray crystal structure analysis}

Crystals of 1, 3 and 10 were obtained in $\mathrm{MeOH}$, respectively. Intensity data were collected at $100 \mathrm{~K}$ on a Bruker APEX DUO diffractometer equipped with an APEX II CCD using $\mathrm{Cu} \mathrm{K} \alpha$ radiation. Cell refinement and data reduction were performed with Bruker SAINT. The structures were solved by direct methods using SHELXS-97. ${ }^{40}$ Refinements were performed with SHELXL-97 and SHELXL-2014 using full-matrix least-squares, with anisotropic displacement parameters for all the nonhydrogen atoms. The $\mathrm{H}$-atoms were placed in calculated positions and refined using a riding model. Molecular graphics were computed with PLATON. ${ }^{41}$ Crystallographic data (excluding structure factor tables) for the structures reported have been deposited with the Cambridge Crystallographic Data Center as supplementary publications no. CCDC 1554050 for $\mathbf{1}$, CCDC 1554052 for 3, and CCDC 1554051 for $\mathbf{1 0}$ † $^{\dagger}$ 
Crystal data for szemaoenoid A (1). $\mathrm{C}_{26} \mathrm{H}_{36} \mathrm{O}_{10} \cdot \mathrm{H}_{2} \mathrm{O}, M=$ 526.56, monoclinic, $a=5.70480(10) \AA, b=23.8602(5) \AA, c=$ 9.3419(2) $\AA, \alpha=90.00^{\circ}, \beta=90.6040(10)^{\circ}, \gamma=90.00^{\circ}, V=$ 1271.53(4) $\AA^{3}, T=100(2) \mathrm{K}$, space group $P 2_{1}, Z=2, \mu(\mathrm{CuK} \alpha)=$ $0.898 \mathrm{~mm}^{-1}, 10232$ reflections measured, 3499 independent reflections $\left(R_{\mathrm{int}}=0.0328\right)$. The final $R_{1}$ values were $0.0300(I>$ $2 \sigma(I))$. The final $\mathrm{w} R\left(F^{2}\right)$ values were $0.0884(I>2 \sigma(I))$. The final $R_{1}$ values were 0.0300 (all data). The final $\mathrm{w} R\left(F^{2}\right)$ values were 0.0885 (all data). The goodness of fit on $F^{2}$ was 1.113. Flack parameter $=$ $0.17(14) .{ }^{29}$ The Hooft parameter is $0.10(6)$ for 1225 Bijvoet pairs. ${ }^{30}$

Crystal data for szemaoenoid $\mathrm{C}(3) \cdot 4\left(\mathrm{C}_{26} \mathrm{H}_{36} \mathrm{O}_{11}\right) \cdot \mathrm{H}_{2} \mathrm{O}, M=$ 2116.20, $a=17.5477(6) \AA, b=21.7199(7) \AA, c=33.3592(12) \AA$, $\alpha=90^{\circ}, \beta=90^{\circ}, \gamma=90^{\circ}, V=12714.3(8) \AA^{3}, T=100(2) \mathrm{K}$, space group $P 22_{1} 2_{1} 2_{1}, Z=4, \mu(\mathrm{CuK} \alpha)=0.728 \mathrm{~mm}^{-1}, 112641$ reflections measured, 23429 independent reflections $\left(R_{\mathrm{int}}=0.0484\right)$. The final $R_{1}$ values were $0.0744(I>2 \sigma(I))$. The final $w R\left(F^{2}\right)$ values were $0.2065(I>2 \sigma(I))$. The final $R_{1}$ values were 0.0759 (all data). The final $\mathrm{w} R\left(F^{2}\right)$ values were 0.2083 (all data). The goodness of fit on $F^{2}$ was 1.044. Flack parameter $=0.11(3){ }^{42}$

Crystal data for szemaoenoid $\mathbf{J}(\mathbf{1 0}) \cdot \mathrm{C}_{20} \mathrm{H}_{26} \mathrm{O}_{5}, M=346.41$, monoclinic, $a=11.5843(7) \AA, b=9.5501(6) \AA, c=15.2093(10) \AA$, $\alpha=90.00^{\circ}, \beta=92.859(4)^{\circ}, \gamma=90.00^{\circ}, V=1680.53(18) \AA^{3}, T=$ $100(2) \mathrm{K}$, space group $P 2_{1}, Z=4, \mu(\mathrm{CuK} \alpha)=0.794 \mathrm{~mm}^{-1}, 10384$ reflections measured, 4801 independent reflections $\left(R_{\text {int }}=\right.$ $0.0536)$. The final $R_{1}$ values were $0.0627(I>2 \sigma(I))$. The final $\mathrm{w} R\left(F^{2}\right)$ values were $0.1682(I>2 \sigma(I))$. The final $R_{1}$ values were 0.0701 (all data). The final $\mathrm{w} R\left(F^{2}\right)$ values were 0.1743 (all data). The goodness of fit on $F^{2}$ was 1.058. Flack parameter $=0.0(2) .{ }^{29}$ The Hooft parameter is 0.01(14) for 1718 Bijvoet pairs. ${ }^{30}$

\section{Acid hydrolysis of szemaoenoid A}

Compound 1 ( $4 \mathrm{mg}$ ) was hydrolyzed with $2 \mathrm{M} \mathrm{HCl} /$ dioxane $(1: 1,4 \mathrm{~mL})$ under reflux for $8 \mathrm{~h}$, respectively. The reaction mixture was partitioned between $\mathrm{H}_{2} \mathrm{O}$ and $\mathrm{CHCl}_{3}(2 \mathrm{~mL} \times 3)$. The aqueous layer was neutralized with $2 \mathrm{M} \mathrm{NaOH}$ and then dried to give a monosaccharide. A solution of the sugar in pyridine $(2 \mathrm{~mL})$ was added to L-cysteine methyl ester hydrochloride (about $1.0 \mathrm{mg}$ ) and kept at $60{ }^{\circ} \mathrm{C}$ for $1 \mathrm{~h}$. Then trimethylsilylimidazole (about $1.0 \mathrm{~mL}$ ) was added to the reaction mixture and kept at $60{ }^{\circ} \mathrm{C}$ for $30 \mathrm{~min}$. The mixture was subjected to GC analysis, run on a Shimadzu GC-14C gas chromatograph equipped with an $\mathrm{H}_{2}$ flame ionization detector. The column was a $30 \mathrm{~m} \times 0.32 \mathrm{~mm}$ i.d. $30 \mathrm{QC} 2 / \mathrm{AC}-5$ quartz capillary column with the following conditions: column temperature, $180-280{ }^{\circ} \mathrm{C}$; programmed increase, $3{ }^{\circ} \mathrm{C} \mathrm{min}^{-1}$; carrier gas, $\mathrm{N}_{2}\left(1 \mathrm{~mL} \mathrm{~min}^{-1}\right)$; injector and detector temperature, $250{ }^{\circ} \mathrm{C}$; injection volume, $4 \mu \mathrm{L}$; and split ratio, $1 / 50$. The configuration of the sugar moiety was determined by comparing the retention time with the derivatives of the authentic samples. The retention times of $\mathrm{D}$-/L-glucose were $21.115 / 21.565$ min. ${ }^{43}$ The configuration of the sugar moiety from compound 1 was D-glucose $\left(R_{\mathrm{t}}=21.117 \mathrm{~min}\right)$.

\section{Cytotoxicity assay}

Human colon adenocarcinoma cell lines, HCT-116 and HT-29 were obtained from the American Type Culture Collection
(ATCC). The cells were cultured in Dulbecco's modified Eagle's medium (DMEM) supplemented with $10 \%$ FBS in a $5 \% \mathrm{CO}_{2}$ atmosphere. HCT-116 $\left(3 \times 10^{3}\right.$ per well $)$ and HT-29 $\left(6 \times 10^{3}\right.$ per well) were seeded onto 96-well plates and allowed to grow for $24 \mathrm{~h}$ prior to treatment. Different concentrations of compounds were then added and further incubated for 3 days. Sorafenib (purity > 99\%; Medchem Express) was used as positive control. The culture medium was replaced by fresh DMEM containing $0.5 \mathrm{mg} \mathrm{mL} \mathrm{m}^{-1}$ of MTT. After incubation for another $4 \mathrm{~h}$, the medium was removed and the reduced formazan blue was solubilized by adding $100 \mu \mathrm{L}$ DMSO to each well. The absorbance at $492 \mathrm{~nm}$ was measured using a microplate reader (Multiskan MK3, Thermo). The $\mathrm{IC}_{50}$ values were calculated from concentration-response curves using Graphpad Prism software.

\section{Antioxidant activity assay}

Trolox (purity > 98\%; Sigma) and vitamin C (Ascorbic acid, purity > 98\%; Sigma) were used as positive control. A $0.1 \mathrm{mM}$ solution of DPPH radical in ethanol was prepared, and $100 \mu \mathrm{L}$ of this solution was mixed with $100 \mu \mathrm{L}$ of sample solution. The mixture was incubated for $5 \mathrm{~min}$ in a dark room at room temperature. Scavenging capacity was read spectrophotometrically by monitoring the decrease in absorbance at $517 \mathrm{~nm}$. DPPH scavenging activity $(\%)=[1-(S-\mathrm{B}) /(C-\mathrm{B})] \times$ $100 \%$, where $S, B$ and $C$ are the absorbencies of the sample, the blank and the control, respectively. ${ }^{44}$

\section{Conclusions}

In summary, we have firstly reported twelve new abietane diterpenoids (1-12) isolated from P. szemaoensis, together with four known compounds (13-16). Structurally, these compounds involved two rearranged-abietane skeletons: $17(15 \rightarrow 16)$-abeoabietane and $17(15 \rightarrow 16), 18(4 \rightarrow 3)$-diabeo-abietane. Their structures with absolute configurations were characterized by a series of spectroscopic methods and X-ray diffraction. In bioactivity assays, compounds 11, 12, 14 and 15 were active against two human colon cancer cell lines (HCT-116 and HT-29) with $\mathrm{IC}_{50}$ values ranging from 8.8 to $34.3 \mu \mathrm{M}$, and compounds 10,13 and 14 exhibited effective free radical scavenging activity with $\mathrm{IC}_{50}$ values ranging from 35.6 to $41.5 \mu \mathrm{M}$ by DPPH experiment. In short, the current study adds to understanding of the chemical composition and biological effects of this plant prepared for green food and ethnodrugs.

\section{Conflicts of interest}

There are no conflicts to declare.

\section{Acknowledgements}

This project was supported financially by the NSFC (81422046, 21762048 and U1702286), the State Key Laboratory of Drug Research (SIMM1705KF-05), and Program for Changjiang Scholars and Innovative Research Team in University (IRT_17R94). 


\section{Notes and references}

$1 \mathrm{~J}$. W. Kadereit, The Families and Genera of Vascular Plants, Springer, Berlin, 2004.

2 J. Pei and S. L. Chen, Zhongguo Zhiwu Zhi, Science Press, Beijing, 1982.

3 S. Habtemariam, BMC Pharmacol., 2003, 3, 6.

4 H. Sudo, T. Ide, H. Otsuka, E. Hirata, A. Takushi and Y. Takeda, Phytochemistry, 1997, 46, 1231-1236.

5 H. Sudo, A. Takushi, E. Hirata, T. Ide, H. Otsuka and Y. Takeda, Phytochemistry, 1999, 52, 1495-1499.

6 N. T. B. Hang, P. T. Ky, C. Van Minh, N. X. Cuong, N. P. Thao and P. Van Kiem, Nat. Prod. Commun., 2008, 3, 1449-1452.

7 V. Shukla, S. C. Phulara, D. Yadav, S. Tiwari, S. Kaur, M. M. Gupta, A. Nazir and R. Pandey, CNS Neurol. Disord.: Drug Targets, 2012, 11, 984-992.

8 D. Y. Wang and S. Y. Xu, Nat. Prod. Res., 2003, 17, 75-77.

9 H. Sudo, A. Takushi, T. Ide, H. Otsuka, E. Hirata and Y. Takeda, Phytochemistry, 1997, 46, 1147-1150.

10 S. B. Lirio, A. P. G. Macabeo, E. M. Paragas, M. Knorn, P. Kohls, S. G. Franzblau, Y. H. Wang and M. A. M. Aguinaldo, J. Ethnopharmacol., 2014, 154, 471-474.

11 K. Y. Niu, L. Y. Wang, S. Z. Liu and W. M. Zhao, J. Asian Nat. Prod. Res., 2013, 15, 1-8.

12 D. Yadav, N. Masood, S. Luqman, P. Brindha and M. M. Gupta, Ind. Crops Prod., 2013, 41, 397-402.

13 J. Lin, B. Yang and J. H. Chen, J. Guangxi Med. Univ., 2001, 2, 207-208.

14 N. Narayanan, P. Thirugnanasambantham, S. Viswanathan, M. Kannappa Reddy, V. Vijayasekaran and E. Sukumar, Fitoterapia, 2000, 71, 147-153.

15 H. P. Pan, Y. Chen, S. H. Jing, M. Lu and G. H. Zhang, Chin. J. Hosp. Pharm., 2007, 07, 861-864.

16 G. Suresh, K. S. Babu, V. R. S. Rao, M. S. A. Rao, V. L. Nayak and S. Ramakrishna, Tetrahedron Lett., 2011, 52, 1273-1276.

17 M. Biradi and K. Hullatti, J. Pharmacol., 2015, 10, 205-208.

18 A. W. Salae, A. Rodjun, C. Karalai, C. Ponglimanont, S. Chantrapromma, A. Kanjana-Opas, S. Tewtrakul and H.-K. Fun, Tetrahedron, 2012, 68, 819-829.

19 S. R. Ayinampudi, R. Domala, R. Merugu, S. Bathula and M. R. Janaswamy, Fitoterapia, 2012, 83, 88-92.

20 Z. Y. Wu, Yunnan Zhiwu Zhi, Science Press, Yunnan province, 1977.

21 S. Liu, H. Zhu, S. Zhang, X. Zhang, Q. Yu and L. Xuan, J. Nat. Prod., 2008, 71, 755-759.

22 M. F. Xu, L. Q. Shen, K. W. Wang, Q. Z. Du and N. Wang, J. Asian Nat. Prod. Res., 2011, 13, 260-264.

23 W. X. Wang, J. J. Zhu, Y. K. Zou, Z. L. Hong, S. T. Liu, M. Li, Y. Huang, J. Xiong, Y. Zhao, G. X. Yang, G. Xia and J. F. Hu, Tetrahedron Lett., 2013, 54, 2549-2552.
24 Q. Liu, H. J. Hu, P. F. Li, Y. B. Yang, L. H. Wu, G. X. Chou and Z. T. Wang, Phytochemistry, 2014, 103, 196-202.

25 X. Tian, Z. Min, N. Xie, Y. Lei, Z. Tian, Q. Zheng, R. Xu, T. Tanaka, M. Iinuma and M. Mizuno, Chem. Pharm. Bull., 1993, 41, 1415-1417.

26 M. F. Xu, L. Q. Shen, K. W. Wang, Q. Z. Du and N. Wang, Nat. Prod. Commun., 2011, 6, 3-5.

27 A. Ulubelen, G. Topcu and S. Olcal, Phytochemistry, 1994, 37, 1371-1375.

28 W. X. Wang, J. Xiong, Y. Tang, J. J. Zhu, M. Li, Y. Zhao, G. X. Yang, G. Xia and J. F. Hu, Phytochemistry, 2013, 89, 89-95.

29 H. D. Flack, Acta Crystallogr., 1983, 39, 876-881.

30 R. W. W. Hooft, L. H. Straver and A. L. Spek, J. Appl. Crystallogr., 2008, 41, 96-103.

31 M. A. Gonzalez, Nat. Prod. Rep., 2015, 32, 684-704.

32 T. Murata, Y. Ishikawa, E. Saruul, E. Selenge, K. Sasaki, K. Umehara, F. Yoshizaki and J. Batkhuu, Phytochemistry, 2016, 130, 152-158.

33 Y. W. Chin, W. P. Jones, Q. Mi, I. Rachman, S. Riswan, L. B. Kardono, H. B. Chai, N. R. Farnsworth, G. A. Cordell, S. M. Swanson, J. M. Cassady and A. D. Kinghorn, Phytochemistry, 2006, 67, 1243-1248.

34 A. Hymavathi, K. Suresh Babu, V. G. Naidu, S. Rama Krishna, P. V. Diwan and J. Madhusudana Rao, Bioorg. Med. Chem. Lett., 2009, 19, 5727-5731.

35 G. Suresh, K. S. Babu, M. S. A. Rao, V. R. S. Rao, P. A. Yadav, V. L. Nayak and S. Ramakrishna, Tetrahedron Lett., 2011, 52, 5016-5019.

36 A. W. Salae and N. Boonnak, Tetrahedron Lett., 2013, 54, 1356-1359.

37 T. Kallio, J. Kallio, M. Jaakkola, M. Maki, P. Kilpelainen and V. Virtanen, J. Agric. Food Chem., 2013, 61, 10720-10729.

38 H. M. Ge, W. H. Yang, J. Zhang and R. X. Tan, J. Agric. Food Chem., 2009, 57, 5756-5761.

39 Y. Yao, W. Sang, M. J. Zhou and G. X. Ren, J. Agric. Food Chem., 2010, 58, 770-774.

40 G. M. Sheldrick and T. R. Schneider, Methods Enzymol., 1997, 277, 319-343.

41 A. L. Spek, Acta Crystallogr., Sect. C: Struct. Chem., 2015, 71, 9-18.

42 H. D. Flack and G. Bernardinelli, Chirality, 2008, 20, 681.

43 P. Y. Liao, D. Wang, Y. J. Zhang and C. R. Yang, Dammarane-type glycosides from steamed notoginseng, J. Agric. Food Chem., 2008, 56, 1751-1756.

44 S. B. Wu, J. Wu, Z. Yin, J. Zhang, C. Long, E. J. Kennelly and S. Zheng, J. Agric. Food Chem., 2013, 61, 4035-4043. 